\title{
Association between the job types and the risk of hepatocellular carcinoma in the United States
}

\author{
Yasmin Abaza ${ }^{1}$, Reham Abdel-Wahab ${ }^{1,2}$, Donghui Li ${ }^{1}$, Ahmed O. Kaseb ${ }^{1}$, Robert A. Wolff ${ }^{1}$, Kanwal Raghav ${ }^{1}$, Ahmed \\ S. Shalaby ${ }^{1}$, Ibrahim Halil Sahin ${ }^{1}$, Jeff Morris ${ }^{3}$, Ernest Hawk ${ }^{4}$, Alexandria T. Phan ${ }^{5}$, Yehuda Z. Patt ${ }^{6}$, Manal M. \\ Hassan*1 \\ ${ }^{1}$ Department of Gastrointestinal Medical Oncology, The University of Texas MD Anderson Cancer Center, Houston, Texas, USA \\ ${ }^{2}$ Department of Clinical Oncology, Faculty of Medicine, Assiut University Hospital, Assiut, Egypt \\ ${ }^{3}$ Department of Biostatistics, The University of Texas MD Anderson Cancer Center, Houston, Texas, USA \\ ${ }^{4}$ Division of Cancer Prevention and Population Science, The University of Texas MD Anderson Cancer Center, Houston, Texas, \\ USA \\ ${ }^{5}$ Department of GI Medical Oncology, Houston Methodist Hospital, Houston, Texas, USA \\ ${ }^{6}$ University of New Mexico (UNM) Health Sciences Center, Albuquerque, NM, USA
}

Received: April 15, 2016

DOI: $10.5430 /$ jer.v3n1p1
Accepted: June 16, 2016

Online Published: August 9, 2016

\begin{abstract}
Background: Hepatocellular carcinoma (HCC) has many well-known predisposing factors including viral hepatitis, alcohol consumption, metabolic syndrome, and cigarette smoking. However, about 30\%-40\% of patients have no identifiable risk factor, indicating the presence of additional causes that are yet to be discovered. Our study aim was to evaluate the association between the risk of HCC and various occupations.

Methods: We conducted a hospital based case-control study that included 589 HCC patients and 1,098 healthy controls. Multivariate unconditioned logistic regression models were done to control for the confounding effects of well-known HCC risk factors.

Results: Female sales workers have a significantly higher risk of HCC; after adjusting for demographic factors, cigarette smoking, drinking alcohol, diabetes mellitus, viral hepatitis, and family history of cancer; the adjusted odds ratio (AOR) and 95\% confidence interval (CI) was (2.8; 1.3-6.0). In contrast, there was a protective association between managers and HCC, which remained statistically significant for females after adjusting for confounding factors (OR, 0.2; CI, 0.05-0.6). With regard to the duration of occupation, sales workers had no increased risk with job duration, whereas managers working for more than 25 years were at lower risk for HCC development.

Conclusion: To the best of our knowledge, this is the first and largest epidemiological study to observe such associations in USA. The underlying biological explanation should be explored in future experimental studies.
\end{abstract}

Key Words: Occupation, Exposure, Hepatocellular carcinoma

\section{INTRODUCTION}

Hepatocellular carcinoma (HCC) is the fifth most common cancer and the second cause of cancer related mortality worldwide. ${ }^{[1-3]}$ The peculiar geographical variation in the incidence of $\mathrm{HCC}$ reflects the variation in the prevalence of $\mathrm{HCC}$ risk factors worldwide. Hepatitis B virus (HBV)

\footnotetext{
*Correspondence: Manal M. Hassan; Email: mhassan@mdanderson.org; Address: Department of Gastrointestinal Medical Oncology, The University of Texas MD Anderson Cancer Center, 1515 Holcombe Blvd, Houston, TX, USA.
} 
is the main risk factor in sub-Saharan Africa and Southeast Asia, accounting for about $80 \%$ of cases, whereas hepatitis $\mathrm{C}$ virus (HCV) is the major cause in North America, Europe, and Japan. ${ }^{[1]}$ Other risk factors include alcohol consumption, cigarette smoking, and metabolic syndrome. ${ }^{[2,4]}$ In the United States, the incidence of HCC has doubled over the past three decades. ${ }^{[2]}$ This dramatic increase in incidence has been attributed primarily to HCV infection. ${ }^{[2]}$ However, about $30 \%-40 \%$ of HCC cases cannot be explained by a wellknown risk factors, indicating the presence of other causes that are yet to be discovered. ${ }^{[3]}$

Given the geographical distribution of HCC, lifestyle and types of work may partially explain such variation between countries. Although large cohort studies have confirmed exposure to vinyl chloride as a risk factor for developing liver angiosarcoma, a similar occupational association has not been established for HCC. ${ }^{[5-7]}$ Some studies have suggested that workers in the food preparation and serving industry, including employees in breweries, distilleries, restaurants, hotels, and bars, are at higher risk of developing HCC, which was partially explained by exposure to alcohol. ${ }^{[8-10]}$ Similarly, health care professionals such as laboratory technicians, surgeons, anesthesiologists, and dialysis nurses were also found to be at higher risk of developing HCC because of their daily exposure to blood or blood products and therefore were at higher risk of acquiring HBV or HCV infections. ${ }^{[11,12]}$ Accordingly, the association between these occupations and $\mathrm{HCC}$ is due to an established connection between the jobs and known risk factors for $\mathrm{HCC}$.

Despite available reports suggesting a possible association between diverse occupational fields and primary liver cancer (PLC), only four epidemiological studies have been conducted specifically for HCC. ${ }^{[9,13-15]}$

In light of the above findings, more studies are needed to assess the actual contribution of occupational exposure as an independent risk factor for HCC development among American population. Therefore, we examine the association between various occupations and the risk of HCC among Americans after adjusting for the potentially confounding main HCC risk factors in our current large-scale case-control study.

\section{Materials AND METHODS}

\subsection{Study design and population}

This study is part of an active case-control study at The University of Texas M.D. Anderson Cancer Center. The study was approved by the Institutional Review Board. ${ }^{[4,16-18]}$ Case patient was pathologically or radiologically diagnosed with HCC who were referred for treatment at gastrointestinal med- ical oncology and surgical oncology outpatient clinics at MD Anderson. All case patients were resided in U.S with no history of other cancers.

The healthy control individuals are defined as healthy subjects without past medical history of malignancy selected from among individuals who accompanied patients with different cancers at The University of Texas M. D. Anderson Cancer Center. To ensure that these individuals had accompanied patients with a variety of cancer types, we approached individuals at the endoscopy, chemotherapy, and diagnostic imaging clinics (computed tomography, magnetic resonance, and tomography imaging). These clinic locations were used for recruitment because they see a large pool of patients with different cancers. All controls included in the study are genetically unrelated family members (such as spouses) of cancer patients who had cancers other than liver, gastrointestinal, lung, or head and neck cancer. Family members and spouses of patients with these cancers were excluded as controls to avoid selection bias due to sharing a common genetic and environmental factors including alcohol consumption, cigarette smoking, viral hepatitis, and family history of cancer. So, the included controls were spouses of patients with breast, prostate, skin, renal, bladder, and gynecological cancers. All controls were healthy and cancer free at time of recruitment. Controls were frequency matched to $\mathrm{HCC}$ case patients by age ( \pm 5 years). We aimed at including all eligible controls who agreed to participate in the study to facilitate stratified analysis by sex.

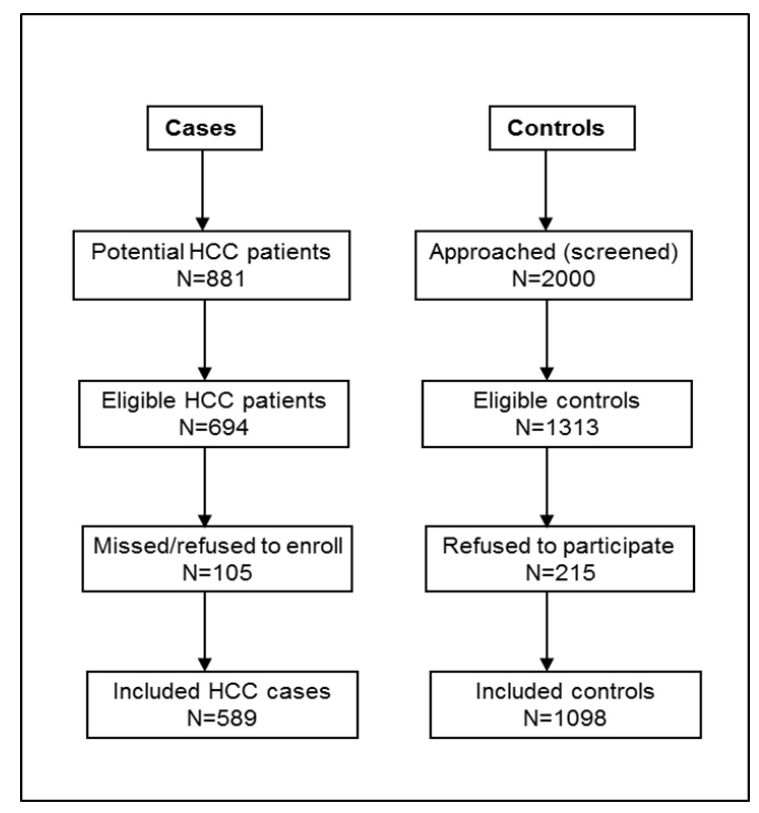

Figure 1. Ascertainment of cases and controls

A short structured questionnaire was used to screen for poten- 
tial controls based on the eligibility criteria. We found that $83.6 \%$ of the eligible control subjects agreed to participate in our risk assessment study (see Figure 1). A comparison between control individuals who agreed to participate in our research and those who refused revealed no significant differences in demographic characteristics and cancer type of their accompanied patients.

We personally interviewed HCC cases and controls for 2530 minutes using a validated structured study questionnaire to collect detailed information about patients' demographics and HCC predisposing factors including viral hepatitis, diabetes mellitus, family history of liver cancer or other cancers, cigarette smoking, and alcohol drinking. Participants considered to be cigarette smokers if they had smoked $\geq$ 100 cigarettes during their lifetimes, and former smokers if they stopped smoking with $\geq 1$ year before study enrollment. Participants considered to be heavy smokers when they had smoked $>20$ pack-years. ${ }^{[4]}$ Also, participants considered to be alcohol drinkers if they had consumed each month at least four alcoholic drinks of beer, wine, or hard liquor for up to 6 months during their lifetimes. Then, we classified drinkers into mild to heavy alcohol drinkers according to the amount of ethanol they consumed in milliliters during their lifetime. ${ }^{[4]}$ Written informed consents from study participants were obtained. For the purpose of the current study we collected detailed histories of occupations and job exposures. Between January 2004 and December 2011, 589 HCC patients and 1,098 healthy controls were eligible and participated in the current investigation. Figure 1 shows ascertainment of eligible cases and controls.

Questions associated with work history included a list of current and prior occupations with duration of each job; job title; job description; and types of tools, equipment, and/or chemicals used. Information regarding previous substance exposure was also collected, including the type of substance and duration of exposure. Finally, all subjects were asked about their site of residence. Those who lived in a highly industrialized area were asked about their duration of residence. For the purposes of this analysis, we included only the occupation of the longest duration, regardless of whether it was the current or previous job. 
Table 1. Association between types of occupation and risk of HCC

\begin{tabular}{|c|c|c|c|c|c|c|}
\hline \multirow{2}{*}{ SOC } & \multirow{2}{*}{ Occupation Classification } & \multirow{2}{*}{$\begin{array}{l}\text { Cases } \\
N=589\end{array}$} & \multirow{2}{*}{$\begin{array}{l}\text { Controls } \\
\mathbf{N}=\mathbf{1 , 0 9 8}\end{array}$} & \multirow{2}{*}{$\begin{array}{l}\text { Univariate } \\
\text { OR (95\% CI) }\end{array}$} & \multirow{2}{*}{$\begin{array}{l}\text { Adjusted* } \\
\text { OR (95\% CI) }\end{array}$} & \multirow{2}{*}{$\begin{array}{l}\text { HCV-/HBV- }{ }^{\#} \\
\text { OR (95\% CI) }\end{array}$} \\
\hline & & & & & & \\
\hline SOC-11 & Management & 54 & 170 & $0.6(0.4-0.8)$ & $0.5(0.3-0.8)$ & $0.6(0.4-0.9)$ \\
\hline SOC-13 & Business and financial operations & 29 & 69 & $0.8(0.5-1.2)$ & $0.8(0.5-1.5)$ & $0.7(0.4-1.4)$ \\
\hline SOC-15 & Computer and mathematical & 6 & 11 & $1.0(0.4-2.8)$ & $0.6(0.1-2.8)$ & $0.9(0.2-4.3)$ \\
\hline SOC-17 & Architecture and engineering & 34 & 54 & $1.2(0.8-1.8)$ & $1(0.7-1.8)$ & $0.9(0.5-1.9)$ \\
\hline SOC-19 & Life, physical, and social science & 6 & 16 & $0.7(0.3-1.8)$ & $1(0.3-3.3)$ & $1.3(0.4-4.1)$ \\
\hline SOC-21 & Community and social service & 11 & 16 & $1.3(0.6-2.8)$ & $1.7(0.6-4.6)$ & $3.1(0.9-9.0)$ \\
\hline SOC-23 & Legal occupations & 12 & 22 & $1.0(0.5-2.1)$ & $1.7(0.7-4.2)$ & $1.5(0.6-3.9)$ \\
\hline SOC-25 & Education, training, and library & 28 & 101 & $0.5(0.3-0.8)$ & $0.9(0.6-1.7)$ & $1.0(0.6-1.7)$ \\
\hline SOC-27 & Arts, design, entertainment, sports, and media & 13 & 19 & $1.3(0.6-2.6)$ & $1.1(0.4-3.0)$ & $1.0(0.3-2.9)$ \\
\hline SOC-29 & Healthcare practitioners and technical & 24 & 64 & $0.7(0.4-1.1)$ & $1.02(0.6-1.9)$ & $0.9(0.4-1.7)$ \\
\hline SOC-31 & Healthcare support occupations & 6 & 6 & $1.9(0.6-5.8)$ & $3.1(0.7-13.3)$ & $3.1(0.7-13.5)$ \\
\hline SOC-33 & Protective service occupations & 14 & 27 & $1.0(0.5-1.9)$ & $1.2(0.5-2.7)$ & $1.2(0.5-2.8)$ \\
\hline SOC-35 & Food preparation/serving related & 11 & 12 & $1.7(0.8-3.9)$ & $0.7(0.2-2.4)$ & $1.2(0.2-5.6)$ \\
\hline SOC-37 & Building/grounds cleaning/maintenance & 31 & 69 & $0.8(0.5-1.3)$ & $1.1(0.6-2)$ & $0.9(0.5-1.7)$ \\
\hline SOC-39 & Personal care and service & 4 & 11 & $0.7(0.2-2.1)$ & $1.7(0.5-6.2)$ & $1.5(0.4-6.2)$ \\
\hline SOC-41 & Sales and related & 47 & 66 & $1.4(1.1-1.9)$ & $1.9(1.2-3.1)$ & $1.9(1.1-3.0)$ \\
\hline SOC-43 & Office and administrative support & 50 & 136 & $0.7(0.5-0.9)$ & $0.9(0.6-1.4)$ & $0.9(0.5-1.4)$ \\
\hline SOC-45 & Farming, fishing, and forestry & 8 & 18 & $0.8(0.4-1.9)$ & $0.9(0.3-2.6)$ & $1.0(0.3-3.0)$ \\
\hline SOC-47 & Construction and extraction occupations & 67 & 62 & $2.1(1.5-3.1)$ & $1(0.6-1.8)$ & $1.1(0.6-2.0)$ \\
\hline SOC-49 & Installation, maintenance, and repair & 40 & 45 & $1.7(1.1-2.6)$ & $0.8(0.4-1.6)$ & $0.7(0.4-1.5)$ \\
\hline SOC-51 & Production occupations & 40 & 62 & $1.2(0.8-1.8)$ & $0.9(0.5-1.6)$ & $0.8(0.4-1.5)$ \\
\hline SOC-53 & Transportation and material moving & 39 & 26 & $2.9(1.8-4.9)$ & $1.4(0.7-2.8)$ & $1.8(0.8-4.0)$ \\
\hline SOC-55 & Military specific occupations & 15 & 16 & $1.8(1.1-3.6)$ & $1.8(0.7-4.5)$ & $1.5(0.5-4.6)$ \\
\hline
\end{tabular}

*Adjusted for age, sex, race, education level, cigarette smoking. Alcohol drinking, diabetes mellitus, family history of cancer, HCV, HBV in all;

\#Adjusted for age, sex, race, education level, cigarette smoking. Alcohol drinking, diabetes mellitus, family history of cancer in absence of chronic HCV or HBV infection.

Table 2. Participants' characteristics

\begin{tabular}{|c|c|c|c|}
\hline & Cases & Controls & \multirow{2}{*}{$P$ value } \\
\hline & $N=589(\%)$ & $N=1,098(\%)$ & \\
\hline \multicolumn{4}{|l|}{ Age (years) } \\
\hline$\leq 40$ & $20(3.4)$ & $50(4.6)$ & \multirow[t]{5}{*}{$\leq .0001$} \\
\hline $41-50$ & $54(9.2)$ & $179(16.3)$ & \\
\hline $51-60$ & $180(30.6)$ & $335(30.5)$ & \\
\hline $61-70$ & $174(29.5)$ & $356(32.4)$ & \\
\hline$>70$ & $161(27.3)$ & $178(16.2)$ & \\
\hline \multicolumn{4}{|l|}{ Sex } \\
\hline Male & $435(73.9)$ & $631(57.5)$ & \multirow[t]{2}{*}{$\leq .0001$} \\
\hline Female & $154(26.1)$ & $467(42.5)$ & \\
\hline \multicolumn{4}{|l|}{ Ethnicity } \\
\hline White & $412(69.9)$ & $967(88.1)$ & \multirow[t]{4}{*}{$\leq .0001$} \\
\hline Hispanic & $79(13.4)$ & $84(7.7)$ & \\
\hline African American & $66(11.2)$ & $39(3.6)$ & \\
\hline Asian & $32(5.4)$ & $8(0.7)$ & \\
\hline \multicolumn{4}{|l|}{ Educational level } \\
\hline$\leq$ High school & $34(5.8)$ & $8(0.7)$ & \multirow[t]{4}{*}{$\leq .0001$} \\
\hline Some college & $233(39.6)$ & $305(27.8)$ & \\
\hline$\geq$ College degree & $318(54.0)$ & $785(71.5)$ & \\
\hline Missing & $4(0.7)$ & $0(0.0)$ & \\
\hline \multicolumn{4}{|l|}{ Hepatitis virus } \\
\hline HCV-/HBV- & $310(52.6)$ & $1,057(96.3)$ & \multirow[t]{4}{*}{$\leq .0001$} \\
\hline $\mathrm{HCV}+/ \mathrm{HBV}-$ & $151(25.6)$ & $7(0.6)$ & \\
\hline $4 \mathrm{HCV}-/ \mathrm{HBV}+$ & $70(11.9)$ & $31(2.8)$ & \\
\hline $\mathrm{HCV}+/ \mathrm{HBV}+$ & $58(9.8)$ & $3(0.3)$ & \\
\hline \multicolumn{4}{|l|}{ Cigarette smoking } \\
\hline No & $183(31.2)$ & $580(52.8)$ & \multirow[t]{2}{*}{$\leq .0001$} \\
\hline$\leq 20 \mathrm{pack} /$ year & $168(28.6)$ & $256(23.3)$ & \\
\hline
\end{tabular}

All of the job titles were coded according to the 2010 Stan- 
dard Occupational Classification (SOC), which was developed by the Office of Management and Budget. ${ }^{[19]}$ The structure of the SOC is comprehensive and designed to incorporate all occupations in the United States economy, including occupations in the public, private, and military sectors. The SOC classifies occupations at four distinct levels: major groups, minor groups, broad occupation, and detailed occupation. The 23 major groups (see Table 1) are divided into 97 minor groups, which in turn are divided into 461 broad occupations. These broad occupations are further divided into 840 detailed occupations. Each job title in the SOC is identified by a six-digit code. The first two digits represent the major group. The third digit represents the minor group. The fourth and fifth digits represent the broad occupation and the sixth digit represents the detailed occupation. For example, 13(-0000) stands for Business and Financial Operations Occupations (major group) and 13-2(000) is equivalent to Financial Specialists (minor group). Inclusion of the fourth and fifth digits signifies the broad occupation, which in this case can be Financial Analysts and Advisors (13-205[0]). The addition of the sixth digit identifies the detailed occupation, which can be Insurance Underwriters (13-2053). In the current study, however, the statistical analysis for job titles was conducted at the two-digit level (i.e., major groups).

Plasma samples were available for only 889 control subjects who were tested, along with all HCC patients, for the presence of HCV antibodies (anti-HCV), HBV surface antigen (HBsAg), and HBV core antibody (anti-HBc).

\subsection{Statistical methods}

We used Microsoft Access to enter and manage the collected information of study participants. Data were analyzed using Stata software (Stata, College Station, TX). The significance of differences in the distributions of categorical variables between cases and healthy controls was determined by Chi-square test. Logistic regression analyses were done to estimate the marginal effects of each work category using maximum-likelihood estimation. All significant risk or protective factors at $p<.05$ from Univariate analyses were taken into consideration to adjust for their confounding effects using multivariate logistic regression analyses. The multivariate adjusted OR (AOR) and 95\% Confidence In- terval (CI) were estimated after controlling for the potential confounding of age, sex, race, education level, and other significant HCC risk factors. Our results were also stratified by sex.

\section{RESULT}

Table 2 shows the demographic characteristics of the 589 patients with HCC and the 1,098 healthy controls. In respect to age distribution, $87.4 \%$ of cases and $79.1 \%$ of controls were older than 50 years. Most of the subjects were Caucasians. Cases were slightly older than controls, with a mean age \pm standard error $(S E)$ of $3.6 \pm 0.5$ years. The overall mean age $( \pm S E$ ) for $\mathrm{HCC}$ cases was $63 \pm 4$ years and for controls was $60 \pm 3$ years. Because we choose frequency matching, not pair matching, we were able to include age in the logistic model to adjust for the slight variation in age distribution that could confound the results.

Education ( $\geq$ college degree) was more frequent among controls $(71.5 \%)$ compared to HCC cases $(54.0 \%)(P \leq .0001)$. Compared with cases (47.4\%), only $3.7 \%$ of controls were infected with HBV or HCV. Heavy alcohol consumption ( $>60$ $\mathrm{g} /$ day) and longstanding diabetes ( $>1$ year) were four times more common in HCC cases than in controls. Similarly, cases were almost twice likely to have a history of extensive cigarette smoking ( $>20$ pack years) compared with controls. Family history of cancer was comparable for both cases and controls. However, the prevalence of family history of liver cancer was significantly higher in cases than in controls.

Table 1 demonstrates the association between various occupations and risk of HCC in all subjects. A positive association was observed between sales workers and HCC, which remained significant after adjusting for other confounding factors and excluding patients with viral hepatitis (1.9 [1.13.0]). A separate analysis of the sexes showed that only female sales workers had a statistically significant risk of HCC (AOR $=2.8$ [1.3-6.0]). Of interest, there was a protective association between managers and HCC, which remained statistically significant for females in multivariate analysis (OR, 0.2; 95\% CI, 0.05-0.6). The remaining occupations did not have a significant association with HCC after adjusting the OR in all and in men and women separately. 
Table 3. Duration of occupation (years) in HCC patients and controls: association with risk of HCC multivariable logistic regression

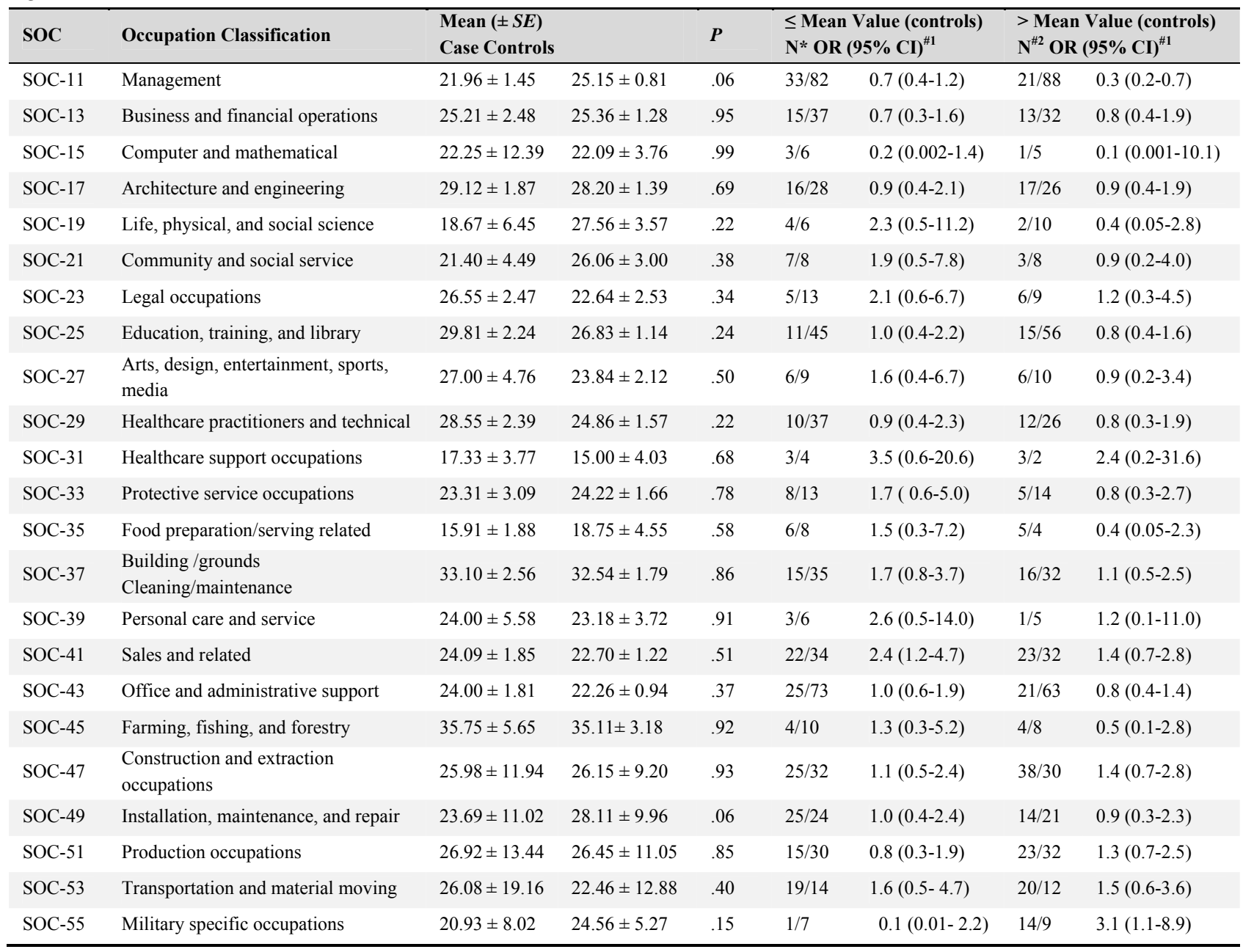

*N: Number of cases/Number of controls with duration of occupation $\leq$ the mean value of the duration (years) for each occupation among control subjects. For example 32 cases and 82 controls worked in management $\leq 25.15$ years;

${ }^{\# 1}$ Adjusted for age, sex, race, education level, cigarette smoking. Alcohol drinking, diabetes mellitus, family history of cancer, HCV, HBV in all;

${ }^{\# 2} \mathrm{~N}$ : Number of cases/Number of controls with duration of occupation $>$ mean value of the duration (years) for each occupation among control subjects. For example 21 cases and 88 controls worked in management for $>25.15$ years.

The relationship between the duration of occupation and risk of HCC is demonstrated in Table 3. The mean value of working years for each job among controls was used as the cut off value for the association between the job duration and HCC (see Table 3). Multivariate logistic regression analysis showed a significant association between HCC and sales workers employed for $\leq 22.70$ years (OR, 2.4; $95 \%$ CI, 1.2-4.7), while, a significant negative association was observed between HCC and managers employed for $>25.15$ years (OR, 0.3; 95\% CI, 0.2-0.7). Interestingly, our results showed that military personnel employed for $>24.56$ years have a higher risk for HCC development (OR, 3.1; 95\% CI, 1.1-8.9).

We found no significant association between HCC and occupational exposure to various chemical agents as asbestos, arsenic, chromium, solvent, glue, paint, pesticides, herbicides, fertilizers, motor oil, gasoline, car or truck exhaust, diesel, dust, fibers, radioactive materials, dry cleaning agents, Polychlorinated Biphen, or plastic exposure.

\section{Discussion}

The results of this investigation showed increased risk for HCC development among sales workers, whereas managers and executives were protected from HCC development. Up to our knowledge, this is the first study to find an association between the occupations of sales workers and managers and risk of HCC development.

Unlike previous studies, we found no significant association between HCC and employees of the food industry, farmers, painters, automobile repairers, plumbers, machinery 
fitters, dry cleaners, printers, and health care professionals. ${ }^{[8,11,13,14,20]}$ This major discrepancy in results can be attributed to numerous limitations in these studies such as small sample sizes; lack of confirmed pathological diagnosis of HCC or pooled analysis for all primary liver cancers including cholangiocarcinoma and angiosarcoma; variation in job stratification; inadequacy of collected data with reliance on death certificates, medical records, tumor registries, and surrogate interviews; and failure to adjust for potential confounding factors such as viral hepatitis, diabetes mellitus, cigarette smoking, and alcohol consumption. We do not know whether strict regulation by Occupational Safety and Health Administration (OSHA) and American National Standards Institute (ANSI) standards in the United States could have any effect on the lack of association between the occupations mentioned earlier and HCC in the U.S. population.

Similarly, sales workers were found to be at high risk of other cancers. Previous studies showed a statistically significant associations between sales workers and both bladder and colon cancers. For example, three studies have suggested that reduced physical activity may explain the increased risk of bladder cancer in sales workers. ${ }^{[21-23]}$ Of note, a study by Chow et al. found a small yet statistically significant risk of colon cancer among sedentary occupations, including administrators, professionals, clerical workers, and sales workers, thereby supporting the proposed inverse relationship between physical activity and colon cancer. ${ }^{[24]}$

In light of the above associations, reduced physical activity may also be the cause of increased risk of HCC in sales workers. A study conducted in Japan showed that the prevalence of obesity and fatty liver was higher among sales workers. ${ }^{[25]}$ Sedentary lifestyle is strongly associated with obesity, which is a major risk factor of metabolic syndrome and its hepatic component, non-alcoholic fatty liver disease (NAFLD). In fact, $75 \%$ of obese individuals experience NAFLD. ${ }^{[26]}$ Nonalcoholic steatohepatitis (NASH), a severe form of NAFLD, can progress to fibrosis, cirrhosis, and eventually to HCC. Preclinical studies have demonstrated that mutated tumor suppressor genes play an important role in the development of steatosis and progression to HCC in NAFLD. ${ }^{[27-29]}$ There is also growing evidence that vascular endothelial growth factor and adipokines secreted by visceral adipose tissue facilitate progression of NASH to HCC by enhancing angiogenesis and upregulating various signal transduction pathways. $^{[30]}$

In our study, managers were at lower risk for developing HCC despite leading sedentary lives, in contrast to the above association. This discrepancy can be attributed to excess

Published by Sciedu Press coffee consumption among managers. Numerous studies have shown an inverse relationship between coffee consumption and HCC development. ${ }^{[31-37]}$ The exact mechanism by which coffee inhibits HCC development remains unclear. Animal studies have shown that coffee induces liver enzymes involved in the detoxification and cellular antioxidant defenses, thereby exerting its protective effect. ${ }^{[38]}$ Potential compounds responsible for the chemoprotective effects of coffee include caffeine, diterpenes (such as cafestol and kahweol), and chlorogenic acid. ${ }^{[37,39-41]}$ Despite being a possible explanation for our observation, we have no data regarding coffee consumption among patients to support this hypothesis.

Furthermore, our study showed that military personnel who were employed for more than 25 years had a 3 times higher risk of developing HCC. This finding was also observed in previous studies but was attributed to the increased rates of HCV in these patients. ${ }^{[42,43]}$ This is not applicable to our study since we adjusted our results for viral hepatitis, suggesting the presence of other contributing factors. Potential causes may include extensive use of dietary supplements ${ }^{[44]}$ and higher rates of human immunodeficiency virus (HIV) infection in this population. ${ }^{[45,46]}$ Preclinical studies have shown that the HIV Tat gene plays a central role in liver carcinogenesis because of its antiapoptotic properties. ${ }^{[46]}$ Whether these are the actual causes for our observation remains unclear.

Our study had numerous strengths. First, we had a large patient population. Second, the data were collected via meticulous interviews with subjects, increasing the accuracy of the gathered information and enabling us to obtain details regarding the occupational exposure and degree of alcohol and tobacco consumption. Third, we were able to adjust for most potential confounding factors associated with HCC including viral hepatitis. Fourth, all of the cases had confirmed diagnosis of HCC. Finally, we used a highly stratified occupation classification system, thereby accentuating important associations. Our study also had a number of limitations. Although the patients were prospectively enrolled, data were retrospectively collected via interviews, increasing the possibility of recall bias. Furthermore, to simplify data analysis, we included only the occupation of longest duration. This elimination may have had a negative effect on our results. In this study, we did not consider the effects of physical activity, body mass index, and dietary factors such as coffee consumption, on the incidence of HCC and therefore cannot validate our hypotheses. To confirm our hypotheses and prove the association between the occupations of sales workers and managers and risk of HCC, we need to conduct a larger study to collect detailed information regarding lifestyle and 
physical activity.

\section{Conclusion}

In conclusion, the impact of occupational exposures and job types on the risk of HCC development is not well studied. The current investigation yielded significant association between specific occupations and HCC development especially among females. Future investigations are warranted to highlight the biological plausibility for the observed association and to assess whether genetic susceptibility to HCC may explain the variation in the risk magnitude between men and women.

\section{ACKNOWLEDGEMENTS}

Supported by: National Institutes of Health grants R03 ES11481 (to M.H.) and CA106458-01 (to M.H.)

\section{CONFlicts OF INTEREST Disclosure}

The authors have declared no conflicts of interest.

\section{REFERENCES}

[1] Kew MC. Hepatocellular carcinoma in developing countries: Prevention, diagnosis and treatment. World J Hepatol. 2012; 4(3): 99-104. PMid:22489262 http://dx.doi.org/10.4254/wjh.v4.i3.99

[2] Mittal S, El-Serag HB. Epidemiology of hepatocellular carcinoma consider the population. J Clin Gastroenterol. 2013; 47 Suppl: S2S6. PMid:23632345 http://dx.doi.org/10.1097/MCG.0b013 e3182872f 29

[3] El-Serag HB. Hepatocellular carcinoma. N Engl J Med. 2011; 365(12): 1118-1127. PMid:21992124 http://dx.doi.org/10. 1056/NEJMra1001683

[4] Hassan MM, Spitz MR, Thomas MB, et al. Effect of different types of smoking and synergism with hepatitis $\mathrm{C}$ virus on risk of hepatocellular carcinoma in American men and women: case-control study. Int J Cancer. 2008; 123(8): 1883-1891. PMid:18688864 http://dx.doi.org/10.1002/ijc. 23730

[5] Mundt KA, Dell LD, Austin RP, et al. Historical cohort study of 10109 men in the North American vinyl chloride industry, 1942-72: update of cancer mortality to 31 December, 1995. Occup Environ Med. 2000; 57(11): 774-781. PMid:11024202 http: //dx.doi.org/10.1136/oem.57.11.774

[6] Ward E, Boffetta P, Andersen A, et al. Update of the follow-up of mortality and cancer incidence among European workers employed in the vinyl chloride industry. Epidemiology. 2001; 12(6): 710-718. PMid:11679801 http://dx.doi.org/10.1097/00001648-200 111000-00021

[7] Kielhorn J, Melber C, Wahnschaffe U, et al. Vinyl chloride: still a cause for concern. Environ Health Perspect. 2000; 108(7): 579-588 PMid:10905993 http://dx.doi .org/10.1289/ehp.00108579

[8] Dossing M, Petersen KT, Vyberg M, et al. Liver cancer among employees in Denmark. Am J Ind Med. 1997; 32(3): 248254. http://dx.doi.org/10.1002/(SICI) 1097-0274(1997 09) $32: 3<248:$ : AID-AJIM10>3 . 0. CO; 2-V

[9] Stemhagen A, Slade J, Altman R, et al. Occupational risk factors and liver cancer. A retrospective case-control study of primary liver cancer in New Jersey. Am J Epidemiol. 1983; 117(4): 443-454. PMid:6837558

[10] Suarez L, Weiss NS, Martin J. Primary liver cancer death and occupation in Texas. Am J Ind Med. 1989; 15(2): 167-175. PMid:2729281 http://dx.doi.org/10.1002/ajim.4700150205

[11] Bruix J, Barrera JM, Calvet X, et al. Prevalence of antibodies to hepatitis $\mathrm{C}$ virus in Spanish patients with hepatocellular carcinoma and hepatic cirrhosis. Lancet. 1989; 2(8670): 1004-1006. http://dx.doi.org/10.1016/S0140-6736(89) 91015-5
[12] Jackson SH, Cheung EC. Hepatitis B and hepatitis C: occupational considerations for the anesthesiologist. Anesthesiol Clin North America. 2004; 22(3): 357-77. http://dx. doi.org/10.1016/j.atc .2004 .04 .001

[13] Ferrand JF, Cenee S, Laurent-Puig P, et al. Hepatocellular carcinoma and occupation in men: a case-control study. J Occup Environ Med. 2008; 50(2): 212-220. PMid:18301178 http://dx.doi.org/10. 1097/JOM. 0b013e31815d88e2

[14] Austin H, Delzell E, Grufferman S, et al. Case-control study of hepatocellular carcinoma, occupation, and chemical exposures. J Occup Med. 1987; 29(8): 665-669. PMid:2821204

[15] Heinemann K, Willich SN, Heinemann LA, et al. Occupational exposure and liver cancer in women: results of the Multicentre International Liver Tumour Study (MILTS). Occup Med (Lond). 2000; 50(6): 422-429. http://dx.doi.org/10.1093/occmed/50.6.422

[16] Hassan MM, Spitz MR, Thomas MB, et al. The association of family history of liver cancer with hepatocellular carcinoma: a casecontrol study in the United States. J Hepatol. 2009; 50(2): 334341. PMid:19070394 http://dx.doi.org/10.1016/j.jhep. 20 08.08 .016

[17] Hassan MM, Kaseb A, Li D, et al. Association between hypothyroidism and hepatocellular carcinoma: a case-control study in the United States. Hepatology. 2009; 49(5): 1563-1570. PMid:19399911 http://dx.doi.org/10.1002/hep. 22793

[18] Hassan MM, Curley SA, Li D, et al. Association of diabetes duration and diabetes treatment with the risk of hepatocellular carcinoma. Cancer. 2010; 116(8): 1938-1946. PMid:20166205 http: $/ / \mathrm{dx}$.doi.org/10.1002/cncr.24982

[19] Occupational outlock handbook [Internet]. US Bureau of Labor Statistics; 2014 [cited 2015 Dec 17]. Available from: http://www.bls . gov/ooh/

[20] Porru S, Placidi D, Carta A, et al. Primary liver cancer and occupation in men: a case-control study in a high-incidence area in Northern Italy. Int J Cancer. 2001; 94(6): 878-883. PMid:11745492 http://dx.doi.org/10.1002/ijc.1538

[21] Mannetje A, Kogevinas M, Chang-Claude J, et al. Occupation and bladder cancer in European women. Cancer Causes Control. 1999; 10(3): 209-217. PMid:10454066 http://dx.doi.org/10.1023 /A: 1008852127139

[22] Tripathi A, Folsom AR, Anderson KE. Lowa Women's Health Study. Risk factors for urinary bladder carcinoma in postmenopausal women. The Iowa Women's Health Study. Cancer. 2002; 95(11): 2316-2323. PMid:12436437 http://dx.doi.org/10.1002/cncr.10975

[23] Ji J, Granstrom C, Hemminki K. Occupation and bladder cancer: a cohort study in Sweden. Br J Cancer. 2005; 92(7): 1276- 
1278. PMid:15770207 http://dx.doi.org/10.1038/sj.bjc. 6602473

[24] Chow WH, Malker HS, Hsing AW, et al. Occupational risks for colon cancer in Sweden. J Occup Med. 1994; 36(6): 647-651. PMid:8071728

[25] Kaneko M, Oda N, Wada N, et al. The study of the relation between the working conditions and the prevalences of obesity, liver disorder and hyperlipidemia: evaluation of physiological examination data during the terms of car manufacturing work and car sales work. Sangyo Eiseigaku Zasshi. 1995; 37(1): 33-41. PMid:7780861 http://dx.doi.org/10.1539/sangyoeisei.37.33

[26] Ertle J, Dechene A, Sowa JP, et al. Non-alcoholic fatty liver disease progresses to hepatocellular carcinoma in the absence of apparent cirrhosis. Int J Cancer. 2011; 128(10): 2436-2443. PMid:21128245 http://dx.doi.org/10.1002/ijc. 25797

[27] Herzer K, Hofmann TG, Teufel A, et al. IFN-alpha-induced apoptosis in hepatocellular carcinoma involves promyelocytic leukemia protein and TRAIL independently of p53. Cancer Res. 2009; 69(3): 855-862. PMid:19141642 http://dx.doi.org/10.1158/0008-5472.CA $\mathrm{N}-08-2831$

[28] Cazanave SC, Mott JL, Elmi NA, et al. JNK1-dependent PUMA expression contributes to hepatocyte lipoapoptosis. J Biol Chem. 2009; 284(39): 26591-26602. PMid:19638343 http://dx.doi.org/10. 1074/jbc.M109. 022491

[29] Bettermann K, Vucur M, Haybaeck J, et al. TAK1 suppresses a NEMO-dependent but NF-kappaB-independent pathway to liver cancer. Cancer Cell. 2010; 17(5): 481-496. PMid:20478530 http: //dx.doi.org/10.1016/j.ccr.2010.03.021

[30] Montella M, Crispo A, Giudice A. HCC, diet and metabolic factors: Diet and HCC. Hepat Mon. 2011; 11(3): 159-162. PMid:22087137

[31] Gallus S, Bertuzzi M, Tavani A, et al. Does coffee protect against hepatocellular carcinoma? Br J Cancer. 2002; 87(9): 956959. PMid:12434283 http://dx.doi .org/10.1038/sj . bjc. 66 00582

[32] Saab S, Mallam D, Cox GA, et al. Impact of coffee on liver diseases: a systematic review. Liver Int. 2014; 34(4): 495-504. PMid:24102757 http://dx.doi.org/10.1111/liv.12304

[33] Bravi F, Bosetti C, Tavani A, et al. Coffee reduces risk for hepatocellular carcinoma: an updated meta-analysis. Clin Gastroenterol Hepatol. 2013; 11(11): 1413-1421. PMid:23660416 http: //dx.doi.org/10.1016/j.cgh.2013.04.039

[34] Jang ES, Jeong SH, Lee SH, et al. The effect of coffee consumption on the development of hepatocellular carcinoma in hepatitis B virus endemic area. Liver Int. 2013; 33(7): 1092-1099. PMid:23651110 http://dx.doi.org/10.1111/liv.12186

[35] Johnson S, Koh WP, Wang R, et al. Coffee consumption and reduced risk of hepatocellular carcinoma: findings from the Singapore Chi- nese Health Study. Cancer Causes Control. 2011; 22(3): 503-510. PMid:21258859 http://dx.doi .org/10.1007/s10552-010-9 $725-0$

[36] Kurozawa Y, Ogimoto I, Shibata A, et al. Coffee and risk of death from hepatocellular carcinoma in a large cohort study in Japan. Br J Cancer. 2005; 93(5): 607-610. PMid:16091758 http://dx.doi.o $\mathrm{rg} / 10.1038 / \mathrm{sj} \cdot \mathrm{bjc} .6602737$

[37] Inoue M, Yoshimi I, Sobue T, et al. Influence of coffee drinking on subsequent risk of hepatocellular carcinoma: a prospective study in Japan. J Natl Cancer Inst. 2005; 97(4): 293-300. PMid:15713964 http://dx.doi.org/10.1093/jnci/dji040

[38] Cavin C, Marin-Kuan M, Langouet S, et al. Induction of Nrf2mediated cellular defenses and alteration of phase I activities as mechanisms of chemoprotective effects of coffee in the liver. Food Chem Toxicol. 2008; 46(4): 1239-1248. PMid:17976884 http: $/ /$ dx.doi.org/10.1016/j.fct.2007.09.099

[39] Tanaka K, Hara M, Sakamoto T, et al. Inverse association between coffee drinking and the risk of hepatocellular carcinoma: a case-control study in Japan. Cancer Sci. 2007; 98(2): 214218. PMid:17233838 http://dx.doi.org/10.1111/j.1349-7 $006.2006 .00368 . x$

[40] Tanaka T, Nishikawa A, Shima H, et al. Inhibitory effects of chlorogenic acid, reserpine, polyprenoic acid (E-5166), or coffee on hepatocarcinogenesis in rats and hamsters. Basic Life Sci. 1990; 52: 429440. http://dx.doi.org/10.1007/978-1-4615-9561-8_45

[41] Peterson S, Yuan JM, Koh WP, et al. Coffee intake and risk of colorectal cancer among Chinese in Singapore: the Singapore Chinese Health Study. Nutr Cancer. 2010; 62(1): 21-29. PMid:20043256 http://dx.doi.org/10.1080/01635580903191528

[42] Jepsen P, Vilstrup HF, Tarone RE, et al. Incidence rates of hepatocellular carcinoma in the U.S. and Denmark: recent trends. Int J Cancer 2007; 121(7): 1624-6. PMid:17557292 http://dx.doi.org/10. 1002/ijc. 22860

[43] Thomas LB, Foulis PR, Mastorides SM, et al. Hepatitis C genotype analysis: results in a large veteran population with review of the implications for clinical practice. Ann Clin Lab Sci. 2012; 42(4): 355-62. PMid:23090730

[44] Thomas DB, Hall AB, Michel M. Non-cirrhotic hepatocellular carcinoma in a young active duty male. Mil Med. 2011; 176(4): 4756. PMid:21539174 http://dx.doi .org/10.7205/MILMED-D-1 0-00295

[45] UNAIDS: AIDS and the Military: Point of View [Internet]. Geneva: United Nations Programme on HIV/AIDS [cited 1998 May]. Availble from: http://data.unaids.org/Publications/IRC-pub 05/militarypv_en.pdf

[46] Nunnari G, Berretta M, Pinzone MR, et al. Hepatocellular carcinoma in HIV positive patients. Eur Rev Med Pharmacol Sci. 2012; 16(9): 1257-70. PMid:23047511 